\title{
Agricultural and Forest Land Use Potential for REDD+ among Smallholder Land Users in Rural Ghana
}

\author{
Divine O. Appiah, ${ }^{1}$ John T. Bugri, ${ }^{2}$ Eric K. Forkuo, ${ }^{3}$ and Sampson Yamba ${ }^{1}$ \\ ${ }^{1}$ Department of Geography and Rural Development, Kwame Nkrumah University of Science and Technology (KNUST), \\ Kumasi, Ghana \\ ${ }^{2}$ Department of Land Economy, Kwame Nkrumah University of Science and Technology (KNUST), Kumasi, Ghana \\ ${ }^{3}$ Department of Geomatic Engineering, Kwame Nkrumah University of Science and Technology (KNUST), Kumasi, Ghana \\ Correspondence should be addressed to Divine O. Appiah; dodameappiah@gmail.com
}

Received 21 September 2015; Revised 4 November 2015; Accepted 23 November 2015

Academic Editor: Piermaria Corona

Copyright (C) 2016 Divine O. Appiah et al. This is an open access article distributed under the Creative Commons Attribution License, which permits unrestricted use, distribution, and reproduction in any medium, provided the original work is properly cited.

Reducing emissions from deforestation and forest degradation with other benefits (REDD+) mechanism is supposed to address the reversal of forest-based land degradation, conservation of existing carbon stocks, and enhancement of carbon sequestration. The Bosomtwe District is predominantly agrarian with potentials for climate change mitigation through REDD+ mechanism among smallholder farmers. The limited knowledge and practices of this strategy among farmers are limiting potentials of mitigating climate change. This paper assesses the REDD+ potentials among smallholder farmers in the district. Using a triangulation of quantitative and qualitative design, 152 farmer-respondents were purposively sampled and interviewed, using snowballing method from 12 communities. Quantitative data gathered were subjected to the tools of contingency and frequencies analysis, embedded in the Statistical Package for Social Sciences (SPSS) v.16. The qualitative data were analyzed thematically. Results indicate that respondents have knowledge of REDD+ but not the intended benefit sharing regimes that can accrue to the smallholder farmers. Farmers' willingness to practice REDD+ will be based on the motivation and incentive potentials of the strategies. The Forestry Services Division should promote the practice of REDD+ among smallholder farmers through education, to whip and sustain interest in the strategy.

\section{Introduction}

Deforestation and forest degradation account for about $17 \%$ of global greenhouse gas emissions [1], making it third to energy (26\%) and industrial (19\%) sectors globally and also higher than the transportation sector [2]. The accelerated loss of tropical forests is recognized globally as a major contributor to global warming [3]. Of the land use and climate interaction, the relationship between agriculture and forests and reducing emissions from deforestation and forest degradation (REDD+) programs is of prime concern [3].

The clearing of tropical forest for agriculture contributes significantly to greenhouse gas emission which hastens climate change. Expanding agricultural lands into forest frontiers for most farmers is a cheaper and preferred way of increasing crop production to meet ever increasing food demands [4]. Beyond reducing the degradation of forests, REDD+ incorporates conservation and sustainable management practices [5]. Reducing emissions from deforestation and forest degradation with forest conservation and management (REDD+) provides the opportunity for host countries to gain financially by costing the value of standing forests, curbing deforestation, and encouraging the conservation and sustainable management of forests. Research by the International Institute for Environment and Development (IIED) has shown that REDD+ strategies will be handicapped if they are not in tandem with national agricultural development objectives focusing on adaptation and mitigation [4].

Communities in forested regions in developing countries are some of the most important stakeholders because REDD+ policies will affect their livelihoods, and these stakeholders will likely be directly involved in the implementation and 
maintenance of REDD+ activities [6]. Through traditional agroforestry practices communities have sustainably managed forests in the past with benefits of increased productivity, sustained soil fertility, erosion control, biodiversity conservation, and income diversification through the harvest and sale of nontimber forest products accruing to them [7]. Reducing emissions from deforestation and forest degradation with its benefits (REDD+) may thus spearhead the restoration of traditional agroecological practices on the continent.

In some African countries, agricultural and environmental sustainability is contextualized in REDD+ policies. In Ethiopia, for example, agricultural systems pose serious threat to the sustainability of the environment and highly contribute to the country's greenhouse gas emissions. Hence REDD+ is anticipated to help reverse this trend [8].

In Tanzania, adopted agroforestry practices include home gardens, alley intercropping, improved fallows, and boundaries [9]. Agroforestry practices in rural communities in Southern Africa include improved fallows, rotational woodlots, and indigenous fruit trees in the parklands system [10]. Bryan et al. [11] and Gledhill et al. [12] emphasized that agroforestry comes with a "triple win" of climate change mitigation, agricultural adaptation, and increased productivity as does REDD+.

REDD+ has been accepted among most African countries because of possible financial benefits through carbon financing to support the forestry sector on the continent. Nevertheless, tenure conflicts based on cultural inheritance pose a threat that hampers development efforts in most African countries [13]. The Agriculture, Forest, and Land Use (AFOLU) and reducing emissions from deforestation and forest degradation (REDD+) interconnection is increasingly gaining attention on the African continent but the realization of actual deforestation and reduction in forest degradation has yet to completely unfold [14].

In [15] Djagbletey and Adu-Bredu found in Nkoranza in Ghana that ownership of teak farms was dominated by natives because tree planting on a parcel of land by an individual customarily implied his or her ownership of the land. Settlers and migrants were therefore less actively involved in tree planting initiatives [15]. According to Adaba [16], in Northern Ghana, families establish woodlots on family lands as alternative sources of income and fuel wood. Communal woodlots are however not popular because individual and family access and utilization of these communal woodlots are usually restricted.

The Cancun agreement states clearly that respect for the rights of local people and the conservation of biodiversity and natural forests must be upheld in the implementation of REDD+ initiatives [17]. REDD+ through avoided deforestation has the potential to reduce GHG emissions. It could conversely result in leakages and increased degradation in adjoining marginal lands [18]. Herein lies the need for agroforestry to absorb such leakages by augmenting the benefits of forests to forest communities and agriculture.

Carbon sequestration in trees initially increases as trees grow but eventually declines as the trees age [19]. Agricultural and forested lands present major carbon sequestration opportunities if the appropriate land use and management practices are adopted [7]. Since agricultural extensification could threaten REDD+, interventions should focus not only on forest but also on forest-farm frontier [17].

Carbon emission reduction through REDD+ can contribute significantly to land-based mitigation in two ways: firstly reducing land-based greenhouse gas emissions and secondly sequestering carbon dioxide through reforestation and agroforestry [20]. Decision on land use at the grassroots involving stakeholders as smallholder must be a key target of REDD+ interventions [17]. The Energy and Resources Institute [21], therefore, recommends that, in order for REDD+ to be effective, there is the need for stratification considering prevailing land use options and patterns.

In this regard, some countries have integrated REDD+ with prevailing land uses including reforestation, afforestation, agroforestry, and assisted natural regeneration using these as key drivers of REDD+ interventions [22]. Smallholders are an important contributor to deforestation. Issues related to land rights are perhaps the most complex and have far-reaching impacts on forest governance, communities, and REDD+ outcomes [23]. To this Kotru [24] asserts that clarity of tenure and hence right to benefits present challenges at the community level. Private land ownership has facilitated the adoption of agroforestry systems in Masaka District since the majority of farmers hold private land. In contrast, other types of land ownership may hinder the adoption of agroforestry systems.

Sebukyu and Mosango [25] put forward that agroforestry practices through REDD+ have benefits of soil fertility restoration, among others, greatly reducing the need for inputs such as fertilizers. Many developing countries are however not adequately prepared to utilize their forest and forestfrontier potentials to benefit from the REDD+ market [26]. More emphasis on educating farmers on the benefits of sustainable resource management and specifically agroforestry and conservation practices would reduce hindrances to the adoption [27]. Critical areas assessed for the purposes of this paper therefore included awareness of REDD+ and its benefits among smallholder farmers in the Bosomtwe District, willingness of smallholder farmers to engage in forest management practices, possible motivation for adoption of REDD+ activities, and land tenure and its potential implication on access to REDD+ benefits.

Problematizing the Concept of REDD+ in the Bosomtwe District. Factors constraining the development of agroforestry among smallholder farmers in the Bosomtwe District are variegated depending on ecological and socioeconomic factors confronting the smallholder farmers. The adoption of agroforestry practices is influenced by many factors and one category of these factors is the characteristics and conditions of the farmer, as has been espoused by Oino and Mugure [28]. Mbwambo et al. [9] explain, for example, that land size, tenure, access to extension services, capital, crop yield, and household income are key in determining farmers adoption of agroforestry.

Rapid population growth within the Bosomtwe District and the Kumasi Metropolis has necessitated increased food supply from nearby agrarian districts as Bosomtwe. 
Periurban developments within the district are increasingly expanding into adjoining arable agricultural lands. This requires that agriculture be sustained by expansion into forest frontiers. Other activities as small-scale mining and wood demands for firewood and charcoal production are on the rise with a current rate of $56.9 \%$ within the district.

The Bosomtwe District being predominantly agrarian with forest cover has potentials for climate change mitigation through REDD+ mechanism among smallholder farmers. Thus, knowledge and practice of smallholder farmers of this strategy as an alternative livelihood potential are critical and practices of this strategy as alternative livelihood potential to their farming activities. Consequently, a substantial proportion of the forest cover is being depleted. Considering the foregone argument, the focus of this paper is to assess the REDD+ potentials among smallholder land users in selected rural communities in the Bosomtwe District of the Ashanti Region of Ghana. In earlier study, the rate of periurbanization was identified as one of the various factors, having depleting impacts on forest land cover in the district [29].

Smallholder land users have access to original forest land covers as well as their potential to engage in other forest regrowth systems in their food production activities. However these potentials appear largely untapped. Furthermore, the enormous potentials of mitigating climate change by reducing emission of agriculture-based carbon dioxide with favorable effects on the local warming and climate variability and change are not adequately studied in the Bosomtwe District. This is the point of departure in making original contribution to the literature in general and in Ghana in particular. The main focus of this paper is therefore to assess the agricultural and forest land use potential for REDD+ among smallholder farmers in the Bosomtwe District of the Ashanti Region of Ghana.

\section{Materials and Methods}

2.1. Profile of the Study Area. The Bosomtwe District is located in the central part of the Ashanti Region. It lies within Latitude $6^{\circ} 28^{\prime} \mathrm{N}$-Latitude $6^{\circ} 40^{\prime} \mathrm{N}$ and Longitude $1^{\circ}$ $20^{\prime} \mathrm{W}$-Longitude $1^{\circ} 37^{\prime} \mathrm{W}$. Kuntanase is the District Capital. It spreads over a land area of $330 \mathrm{~km}^{2}$ (Figure 1). The district is bounded to the north by Atwima Nwabiagya and Kumasi Metropolis and to the east by Ejisu-Juaben Municipal. The southern section is bounded by Amansie West and East Districts, all in the Ashanti Region of Ghana.

Lake Bosomtwe, the largest natural (crater) lake in West Africa, is located in the district [30]. The lake is also one of the main sources of livelihood for 24 communities living around it [29]. With the exception of the lake which has an outer ridge that maintains a constant distance of $10 \mathrm{~km}$ from the center of the lake and stands at an elevation of 50 to $80 \mathrm{~m}$, the rest of the district has no other varying unique topographical features.

The drainage pattern of rivers and streams draining the Bosomtwe District is dendritic and centripetal in outlook. Around Lake Bosomtwe, there is internal drainage where the streams flow from surrounding highlands into the lake in a centripetal fashion. The streams form a dense network due

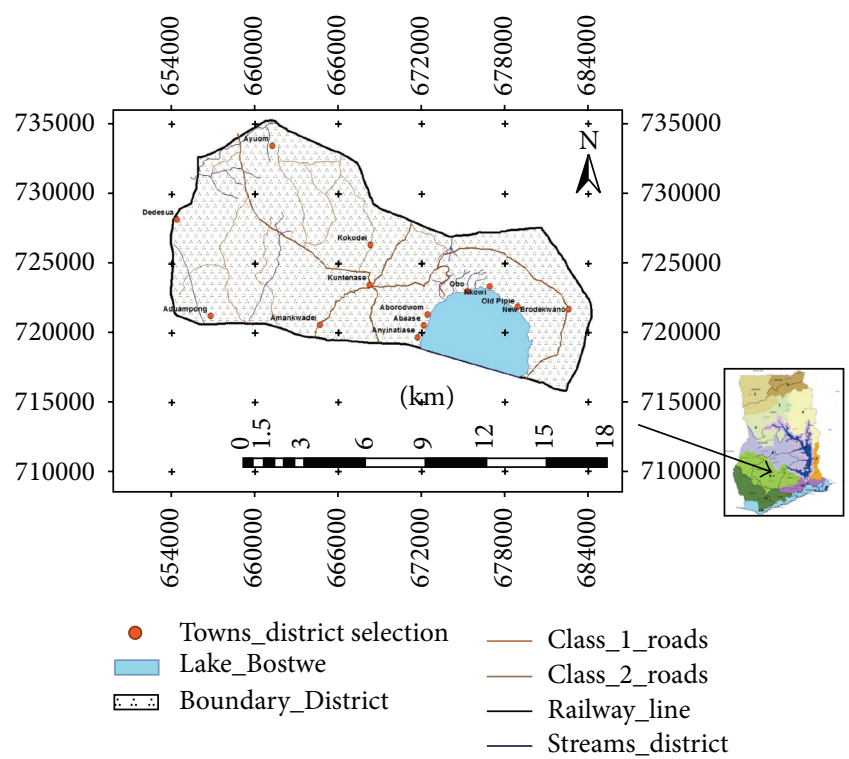

FIgure 1: The map of the Bosomtwe District in Ghana.

to the double maxima rainfall regime. Notable rivers in the district are Rivers Oda, Butu, Siso, Supan, and Adanbanwe.

The district is within the moist semideciduous forest ecological zone with a major and a minor rainfall regime. The major rainfall regime is from March to July while the minor one is from September to November. The zone has mean annual rainfall and mean monthly temperature of about $1,900 \mathrm{~mm}$ and $36^{\circ} \mathrm{C}$, respectively. Relative humidity ranges between $60 \%$ and $85 \%$ [31].

The district falls within the moist semideciduous forest zone where different species of tropical hard woods with high economic value can be found. The trees species found in the district include wawa (Triplochiton scleroxylon), denya (Cylicodiscus gabunensis), mahogany (Khaya ivorensis), asanfena (Aningeria spp.), and onyina (Ceiba pentandra). However, due to extensive farming activities in the area, the original vegetation has been degraded to a mosaic of secondary forest, thicket, and regrowth with abandoned farms of food crops and vegetables.

In certain parts of the district, however, the original forest cover has been turned into secondary forest and grassland through indiscriminate exploitation of timber and inappropriate farming practices such as the slash and burn system and illegal gold mining activities.

The population of the district according to the Ghana Statistical Service Census is 93,910 with an urban to rural population ratio of approximately $1: 2$ [32]. Proximity of the district to the Kumasi Metropolis is greatly encouraging the growth of settlement in the district. Moreover, the district's tourism potential has drawn a lot of investments in infrastructure development and other socioeconomic activities into the district [29].

2.2. Sampling Design, Instruments, and Data Analysis. The study analyzes agricultural and forest land use potential for 
REDD+ among smallholder farmers in the Bosomtwe District. The purposive cluster sampling technique was used to select 12 communities from which 152 smallholder farmers were sampled and data solicited from them. The respondents for the study were sampled using snowball sampling technique because of the difficulty of locating the smallholder farmers as the target population. This was to ensure that the required target respondents (smallholder farmers) were accessed [33]. Using a semistructured partially precoded questionnaire, we administered proportionately to the communities based on their respective population sizes according to the 2011 District Assembly Scalogram. The Scalogram is the table that details the socioeconomic profile of the district in terms of the percentage availability of social and economic infrastructure. Field observation was also done to facilitate the understanding of possible physical features of the communities that have bearing on the study.

The quantitative data gathered were subjected to frequencies analysis embedded in the Statistical Package for Social Sciences (SPSS) v.16, for Windows application. The results are displayed in tables, charts, and graphs. The diagrams generated in the SPSS were exported to Excel for editing for better visual presentation. Open-ended qualitative responses were integrated in the discussions under the various thematic treatments of the sections of the paper.

\section{Results and Discussions}

3.1. Smallholder Farmers' Knowledge of REDD+. Elbehri et al. [34] espoused that some arguments remain that agriculture is a driver of deforestation in REDD+. The knowledge of REDD+ among smallholder farmers was ascertained. This revealed that awareness of reducing emissions from deforestation and forest degradation (REDD+) and its benefits was diminutive among smallholder farmers in the Bosomtwe District. From Figure 2, only one percent of respondents indicated knowing what REDD+ meant and stood for and the benefits thereof for developing countries (and other stakeholders). The remaining 99\% have never heard of REDD+. According to Madeira [6] although the focus of international discourse on REDD+ is on credit design and policy, its success depends on the practicality of implementation in host countries and among local stakeholders.

This is equally premised on their awareness and understanding of what REDD+ is and the appreciation of their role in the implementation of these policies at the local level. Streed et al. [35] posit that ill-informed stakeholders and beneficiaries could unknowingly sell their carbon rights to others even with a policy of equitable distribution of benefits. It is therefore very necessary that these stakeholders be appropriately educated on what REDD+ is, associated responsibilities, and its accruing benefits accordingly.

Although the potentials to achieve climate change mitigation using REDD+ begin with its design, actualization of its purposes lies with the commitment of grassroot stakeholders to this cause [6]. In soliciting for the willingness of farmers to trade off their immediate gains of cutting down trees for future REDD+ benefits, it was found that the majority of the farmers are willing to utilize immediate benefits of cutting

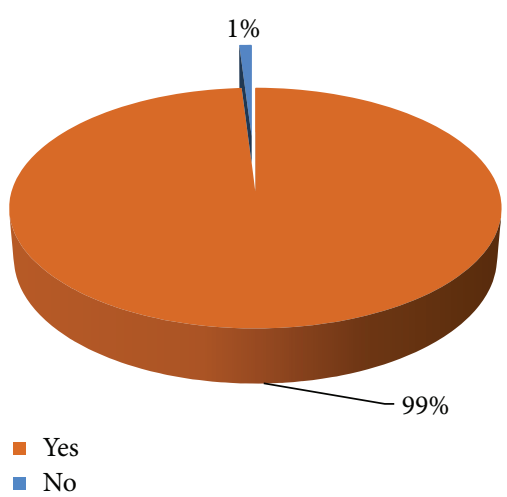

Figure 2: Knowledge of REDD+ in the Bosomtwe District.

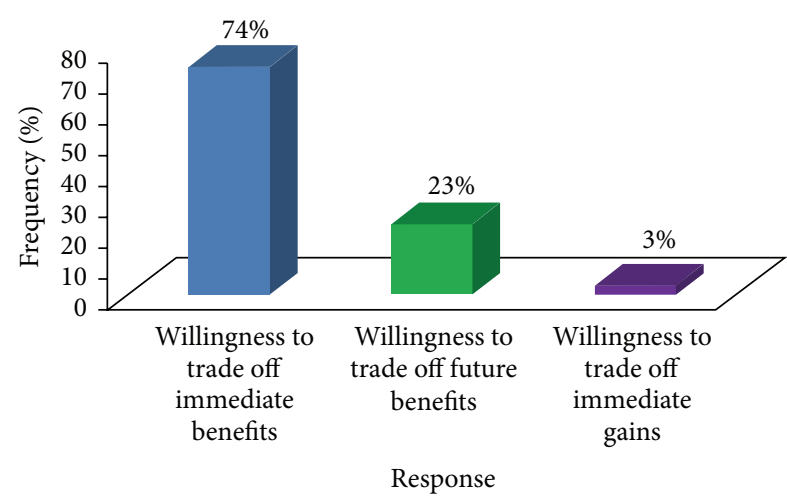

FIGURE 3: Decision on trading off future gains from tress for present needs.

down trees and planting new ones instead. A few were willing to trade off future benefits of REDD+ for present gains (without replanting) and much fewer respondents willing to trade immediate gains of cutting down trees for future benefits from the trees (Figure 3). Farmers did not expect to benefit immediately from preservation of trees. Consequently, trading off their immediate and primary source of livelihood for benefits that may not be forthcoming in the short term did not seem motivating enough to engage in the REDD+ mechanism. Some farmers were also much more willing to cut down the tress owing to the perceived notion of some shade intolerant crops which may not thrive well under trees.

In the same vein, it was found that their willingness to be involved in REDD+ activities was based on training and other supportive measures. This is because most of the smallholder farmers (being 66\%) indicated that they were very willing to be involved in REDD+ initiatives if the necessary training and support are provided while $29 \%$ were quite willing to engage in REDD+ activities. Only seven percent were not willing to be involved in these activities. This agrees with findings by Banerjee-Woien [36] who asserts that, in Indonesia, the willingness of indigenous people was essential in determining the success of REDD+ initiatives.

Using three benefits of REDD+ as benchmarks, the motivation for smallholder farmers in the Bosomtwe District to be involved in REDD+ initiatives was ascertained. These were 


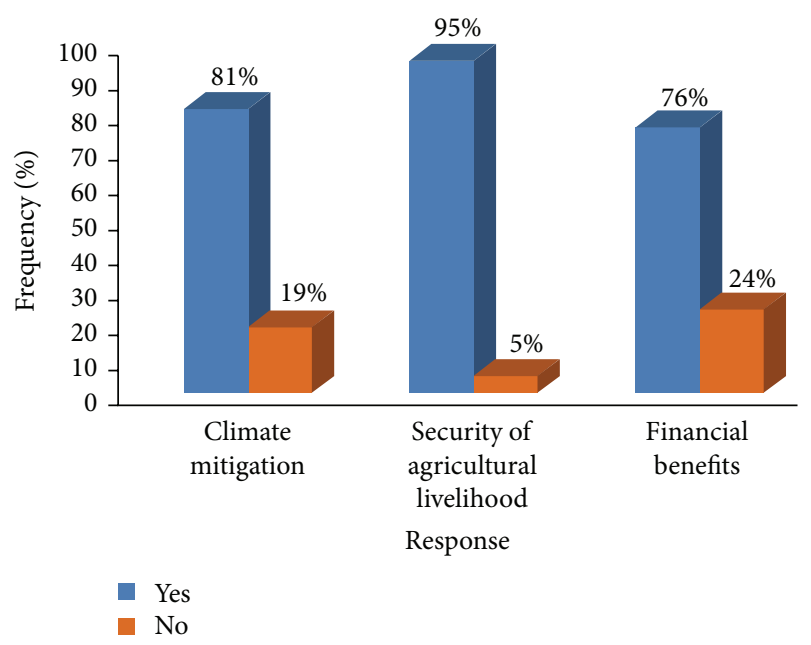

FIgURE 4: Motivation for willingness to be engaged in REDD+ initiatives.

climate mitigation, security of agricultural livelihood, and possible financial benefits. It was found that interest in REDD+ initiatives is underpinned by benefits of climate mitigation, security of agricultural livelihood, and possible financial benefits that could accrue to smallholder farmers and the local communities as a whole. This is shown in Figure 4.

It is quite obvious that smallholder farmers in the district keenly have their livelihood at heart, as the need to secure agricultural livelihood recorded the highest responses, as a motivating factor for the adoption of REDD+ initiatives. Therefore, whether REDD+ does, in fact, deliver on its promised benefits and avoid adverse impacts strongly depends on, among others, fair and equitable benefit sharing, land and carbon tenure in favor of communities, and full and effective participation [37].

3.2. Relationship between Land Tenure Arrangement and $R E D D+$ Benefits. Creating effective carbon benefit sharing must not lose sight of prevailing land tenure systems, forest and natural resource related livelihoods, and territories [38]. Respondents were required to indicate the land tenure systems they subscribe to and their potential implications for REDD+ in relation to land use. It was found that land tenure system in Bosomtwe District among smallholder farmers is predominantly self-owned as can be seen in Figure 5. Hence $76 \%$ of smallholder farmers own their farmlands, $12 \%$ of farmlands belong to the families of the farmers, and $12 \%$ are leased.

This presupposes that it is quite clear who should be considered in the formulation and implementation of agroforestry projects as well as their respective roles and benefits.

Reference [38] notes that the challenge of potential tenure conflicts could be aggravated by the increased value of land due to carbon benefits accruing from the implementation of REDD+. There is little anticipation among smallholder farmers of increased interest in farmland by land owners because farmland is predominantly self-owned and benefits would accrue to them. Hence, $85 \%$ do not anticipate an increased

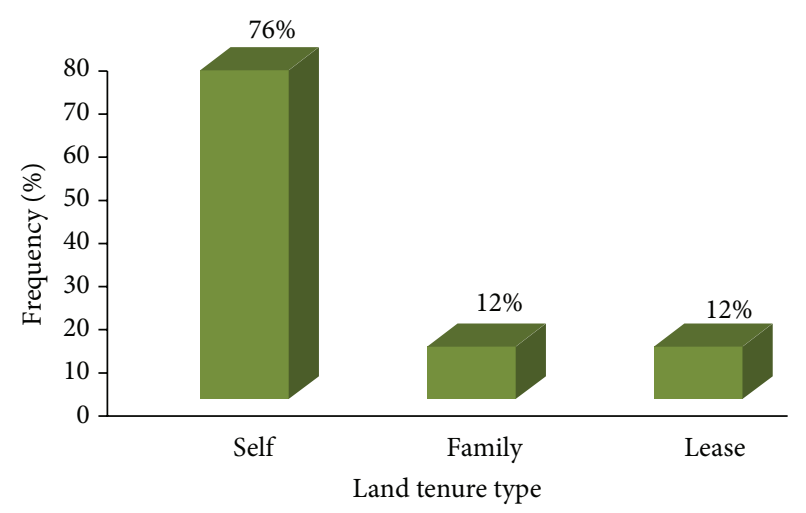

FiguRE 5: Land tenure arrangements among smallholder farmers.

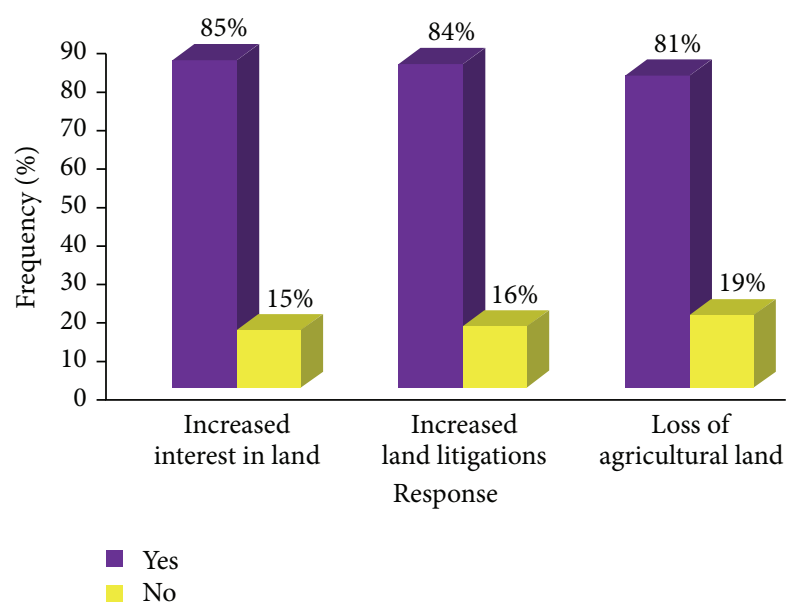

FIGURE 6: Implications for access to REDD+ benefits.

interest in farmland by land owners while $15 \%$ think otherwise. This trend is equally made manifest in their response to the possibility of increase in land litigations due to access to REDD+ benefits. Whiles the majority were not anticipating an increase in land litigation, a few of the respondents do anticipate that an increase in land litigation may likely be an outcome. Figure 3 shows smallholder farmers response to possible implications of access to REDD+ benefits.

Incidentally, while only a small proportion of the respondents do not anticipate a reduction in agricultural land anticipating a competing land use change with the introduction of REDD+ activities, a substantial proportion do anticipate otherwise (Figure 6). Those who anticipated a reduction in agricultural land attributed it to the shade that trees provide and the root systems of trees being less favorable for the tilling of land. The majority who indicated no reduction in agricultural land explained that trees were more helpful and improved soil moisture and nutrients which would buffer reduction in land area due to trees planted.

The Forest Investment Program (FIP), one of the climate funds that target forests and REDD+ activities, had a target ranging from US $\$ 1$ billion to US $\$ 2$ billion to support, among other activities, REDD+, afforestation, and sustainable forest 
management [39]. Grieg-Gran [4] suggests that forest conservation initiative should necessarily support alternative income generation activities among forest communities, sustainable agricultural practices, and agroforestry. Engaging in afforestation and other forest regeneration projects is likely to have implication for agricultural activities at the household scale. Although $64 \%$ of smallholder farmers are willing to practice agroforestry as compared to $27 \%$ willing to use part of their farms for afforestation, only one percent are willing to convert their entire current cropping system into farm for afforestation, with seven percent not willing to engage in agroforestry or afforestation. The latter's justification for opting out was based on concerns of the possible loss of agricultural land through afforestation and agroforestry.

This is because land is scarce and crops do not do well in the shade. They therefore anticipate that, with the adoption of either practice, agriculture on such lands will invariably not be sustainable. Devoting the entire land to afforestation thereby becomes an inevitable option. It however remains that sustainable agricultural and forest land use and conservation are favorable for the majority of smallholder farmers in the district.

\section{Conclusion}

Conservation agriculture constitutes an important component for successful REDD+ programs. Awareness of REDD+ and its benefits is low among smallholder farmers in the Bosomtwe District. However, farmers are willing to engage in activities that are geared towards sustainable environmental resource use and conservation. Herein lies the potential for the implementation of REDD+ in the district for local, national, and global benefits. The majority of smallholder farmers in the Bosomtwe District are willing to utilize immediate benefits of cutting down trees and plant new ones instead because they do not expect to benefit immediately from preservation of trees.

Consequently trading off their immediate and primary source of livelihood for benefits that may not be forthcoming in the short term does not seem appropriate. Benefits from REDD+ reaching the grassroots will accrue to farmers as land is generally self-owned. This is one motivating factor for their willingness to engage in REDD+ and related projects. By contributing to the literature, this paper proffers the need for policy to be directed towards the protection of marginal agricultural lands. This would ensure continuous local and regional monitoring of agriculture and forest land use practices in the Bosomtwe District and Ghana.

\section{Conflict of Interests}

There is no conflict of interests regarding the publication of this paper.

\section{Acknowledgments}

The authors acknowledge the financial support from the West African Science Service Centre for Adapted Land Use (WASCAL) as well as the German Ministry of Higher Education and Research. They also thank the Department of Geography and Rural Development for their provision of office space and logistics. They thank Miss Lois Antwi-Boadi for her careful proofreading of this paper.

\section{References}

[1] IPCC, "Climate change 2007: impacts, adaptation, and vulnerability," Contribution of Working Group II to the Fourth Assessment Report, Cambridge University Press, Cambridge, UK, 2007.

[2] UN-REDD, "Frequently Asked Questions and Answers-The UN-REDD Programme and REDD+," November 2010, http:// www.unep.org/forests/Portals/142/docs/UN-REDD\%20FAQs\% 20\%5B11.10\%5D.pdf.

[3] Japan International Cooperation Agency (JICA) and International Tropical Timber Organization (ITTO), Reducing Emissions from Deforestation and Forest Degradation in Developing Countries; The Role of Conservation, Sustainable Management of Forests and Enhancement of Forest Carbon Stocks in Developing Countries, 2nd edition, 2012, http://www.itto.int/files/user/pdf/ publications/Other\%20Publications/op-20\%20e\%20j.pdf.

[4] M. Grieg-Gran, Beyond forestry: why agriculture is key to the success of REDD+, A Briefing, November 2010, http://www .iied.org/pubs/display.php?o=17086IIED.

[5] H. Reid, M. Chambwera, and L. Murray, "Tried and tested: learning from farmers on adaptation to climate change," Gatekeeper, 153, 2013, http://pubs.iied.org/pdfs/14622IIED.pdf.

[6] E. C. M. Madeira, Policies to Reduce Emissions from Deforestation and Degradation (REDD+) in Developing Countries: An Examination of the Issues Facing the Incorporation of REDD+ into Market-Based Climate Policies, Resources for the Future, Washington, DC, USA, 2008.

[7] B. Bishaw, H. Neufeldt, J. Mowo et al., Farmers' Strategies for Adapting to and Mitigating Climate Variability and Change through Agroforestry in Ethiopia and Kenya, edited by: C. M. Davis, B. Bernart, A. Dmitriev, Forestry Communications Group, Oregon State University, Corvallis, Ore, USA, 2013.

[8] A. Wilkes, T. Tennigkeit, and K. Solymosi, National Integrated Mitigation Planning in Agriculture: A Review Paper, Mitigation of Climate Change in Agriculture (MICCA), Food and Agriculture Organization of the United Nations (FAO), Rome, Italy, 2013, http://mahider.ilri.org/handle/10568/27782.

[9] J. S. Mbwambo, P. L. Saruni, and G. S. Massawe, "Agroforestry as a solution to poverty in rural Tanzania. Lessons from Musoma Rural District, Mara Region, Tanzania," Kivukoni Journal, vol. 1, no. 2, pp. 15-30, 2013.

[10] K. F. Kalaba, P. Chirwa, S. Syampungani, and O. C. Ajayi, "Contribution of agroforestry to biodiversity and livelihoods improvement in rural communities of Southern African regions," in Tropical Rainforests and Agroforestry under Global Change, Ecological and Socio-Economic Valuations, T. Tscharntke, C. Leuschner, E. Veldkamp, H. Faust, E. Guhardja, and A. Bidin, Eds., pp. 461-476, Springer, New York, NY, USA, 2010.

[11] E. Bryan, C. Ringle, B. Okoba, I. Koo, M. Herrero, and S. Sivestri, Agricultural Land Management: Capturing Synergies among Climate Change Adaptation, Greenhouse Gas Mitigation, and Agricultural Productivity, International Food Policy Research Institute IFPRI, Washington, DC, USA, 2011. 
[12] R. Gledhill, C. Herweijer, D. Hamza-Goodacre, J. Grant, C. Webb, and J. Steege, "Agricultural carbon markets: opportunities and challenges for Sub-Saharan Africa," Rockefeller Foundation, 2011, https://www.pwc.co.uk/assets/pdf/agriculturalcarbon-markets.pdf.

[13] Sahara and Sahel Observatory, Comprehensive Framework of African Climate Change Programmes, Sahara and Sahel Observatory, 2010, http://www.unep.org/roa/amcen/Amcen_Events/ 4th_ss/Docs/AMCEN-SS4-INF-3.pdf.

[14] Common Market for Eastern and Southern Africa (COMESA), "Programme on Climate Change Adaptation and Mitigation in the Eastern and Southern Africa (COMESA-EAC-SADC) Region," 2011, http://www.sadc.int/files/9613/5293/3510/COMESAEAC-SADC_Climate_Change_Programme_2011.pdf.

[15] G. D. Djagbletey and S. Adu-Bredu, "Adoption of agroforestry by small scale teak farmers in Ghana-the case of Nkoranza district," Ghana Journal of Forestry, vol. 20, no. 21, pp. 1-13, 2007.

[16] G. B. Adaba, Natural resource management, governance and globalisation [M.S. thesis], Centre For Transdisciplinary Environmental Research, Stockholm University, Stockholm, Sweden, 2005.

[17] J. N. H. Scriven and Y. Malhi, "Smallholder REDD+ strategies at the forest-farm frontier: a comparative analysis of options from the Peruvian Amazon," Carbon Management, vol. 3, no. 3, pp. 265-281, 2012.

[18] R. W. Gorte and J. L. Ramseur, "Forest carbon markets: potentials and drawbacks," CRS Report for Congress RL 34560, Congressional Research Service, Washington, DC, USA, 2008.

[19] FAO, "Managing forests for climate change: FAO, working with countries to tackle climate change through sustainable forest management," 2010, http://www.fao.org/docrep/013/i1960e/ i1960e00.pdf.

[20] Tanzania National REDD+ Task Force, Preparing for the REDD+ Initiative in Tanzania: A Synthesized Consultative Report Compiled by Institute of Resources Assessement, University of Dar es Salaam for National REDD+ Task Force, Dar es Salaam, Tanzania, 2009.

[21] The Energy and Resources Institute (TERI), "Adaptation to climate change in the context of sustainable development, United Nations Department of Economic and Social Affairs, Division for Sustainable Development, Climate Change and Sustainable Development: A Workshop to Strengthen Research and Understanding, New Delhi, 7-8 April," 2013, http://www.teriin .org/events/docs/adapt.pdf.

[22] G. Kissinger, M. Herold, and V. De Sy, Drivers of Deforestation and Forest Degradation: A Synthesis Report for Redd+ Policymakers, Lexeme Consulting, Vancouver, Canada, 2012.

[23] E. Jurgens, W. Kornexl, C. Oliver, T. Gumartini, and T. Brown, "Integrating communities into REDD+ in Indonesia," Working Paper, PROFOR, Washington, DC, USA, 2013.

[24] R. Kotru, "Nepal's national REDD+ framework: how to start?" Journal of Forest and Livelihood, vol. 8, no. 1, pp. 1-6, 2009.

[25] V. B. Sebukyu and D. M. Mosango, "Adoption of agroforestry systems by farmers in Masaka District of Uganda," Ethnobotany Research and Applications, vol. 10, pp. 59-68, 2012.

[26] E. Streed, S. Hajost, and M. Sommervile, "USAID program brief forest carbon, markets and communities," A Program Managed by the Natural Resources Management Office Of USAID, 2012, http://www.fcmcglobal.org/documents/FinanceandCarbonMarketsLexiconFinal40clean.pdf.
[27] World Agroforestry Centre, Socio-Economic Analysis of Farmers' Potential for Adoption of Evergreen Agriculture in Bugesera District, Rwanda, World Agroforestry Centre, Nairobi, Kenya, 2008.

[28] P. Oino and A. Mugure, "Farmer oriented factors that influence adoption of agroforestry practices in Kenya: experiences from Nambale District, Busia County," International Journal of Science and Research, vol. 2, no. 4, pp. 450-456, 2013.

[29] D. O. Appiah, J. T. Bugri, E. K. Forkuor, and P. K. Boateng, "Determinants of peri-urbanization and land use change patterns in Peri-Urban Ghana," Journal of Sustainable Development, vol. 7, no. 6, pp. 95-109, 2014.

[30] O. D. Anim, Y. Li, A. K. Agadzi, and P. N. Nkrumah, "Environmental issues of Lake Bosomtwe impact crater in Ghana (West Africa) and its impact on ecotourism potential," International Journal of Scientific \& Engineering Research, vol. 4, no. 1, pp. 1-9, 2013.

[31] S. Prakash, P. Wieringa, B. Ros et al., "Socio-economics of forest use in the tropics and subtropics: potential of ecotourism development in the Lake Bosumtwi Basin a case study of ankaase in the Amansie East District, Ghana," SEFUT Working Paper 15, Albert-Ludwigs-Universität Freiburg, Freiburg im Breisgau, Germany, 2005.

[32] Ghana Statistical Service, 2010 Populaiton and Housing Census, Summary Report of Final Results, Ghana Statistical Service, Accra, Ghana, 2010, http://www.statsghana.gov.gh/docfiles/2010phc/Census2010_Summary_report_of_final_results.pdf.

[33] H. Katz, "Global surveys or multi-national surveys? On sampling for global surveys," in Proceedings of the Thoughts for the Globalization and Social Science Data Workshop, p. 6, UCSB, November 2006, http://www.global.ucsb.edu/orfaleacenter/ conferences/ngoconference/Katz_for-UCSB-data-workshop.pdf.

[34] A. Elbehri, A. Genest, and M. Burfisher, Global Action on Climate Change in Agriculture: Linkages to Food Security, Markets and Trade Policies in Developing Countries, Trade and Markets Division, FAO, Rome, Italy, 2011.

[35] E. Streed, S. Hajost, and M. Sommervile, "USAID Program Brief Forest Carbon, Markets and Communities: A Program Managed by the Natural Resources Management Office of USAID," 2012, http://www.fcmcglobal.org/documents/FinanceandCarbonMarketsLexiconFinal40clean.pdf.

[36] T. Banerjee-Woien, Trust: a precondition for successful implementation of REDD+ initiatives? [M.S. thesis], University of Agder, Kristiansand, Norway, 2010.

[37] Tanzania Natural Resource Forum, "REDD+ Realities: Learning from REDD+ pilot projects to make REDD+ work," 2011, http://www.tnrf.org/files/e-REDD\%20Realities.pdf.

[38] UN-REDD+, “The UN-REDD+ Programme Strategy 20112015," 2013, http://www.tnrf.org/files/e-REDD\%20Realities.pdf.

[39] T. Griffiths, Seeing REDD+? Avoided Deforestation and the Rights of Indigenous Peoples and Local Communities, Forest Peoples Programme, Gloucestershire, UK, 2007. 

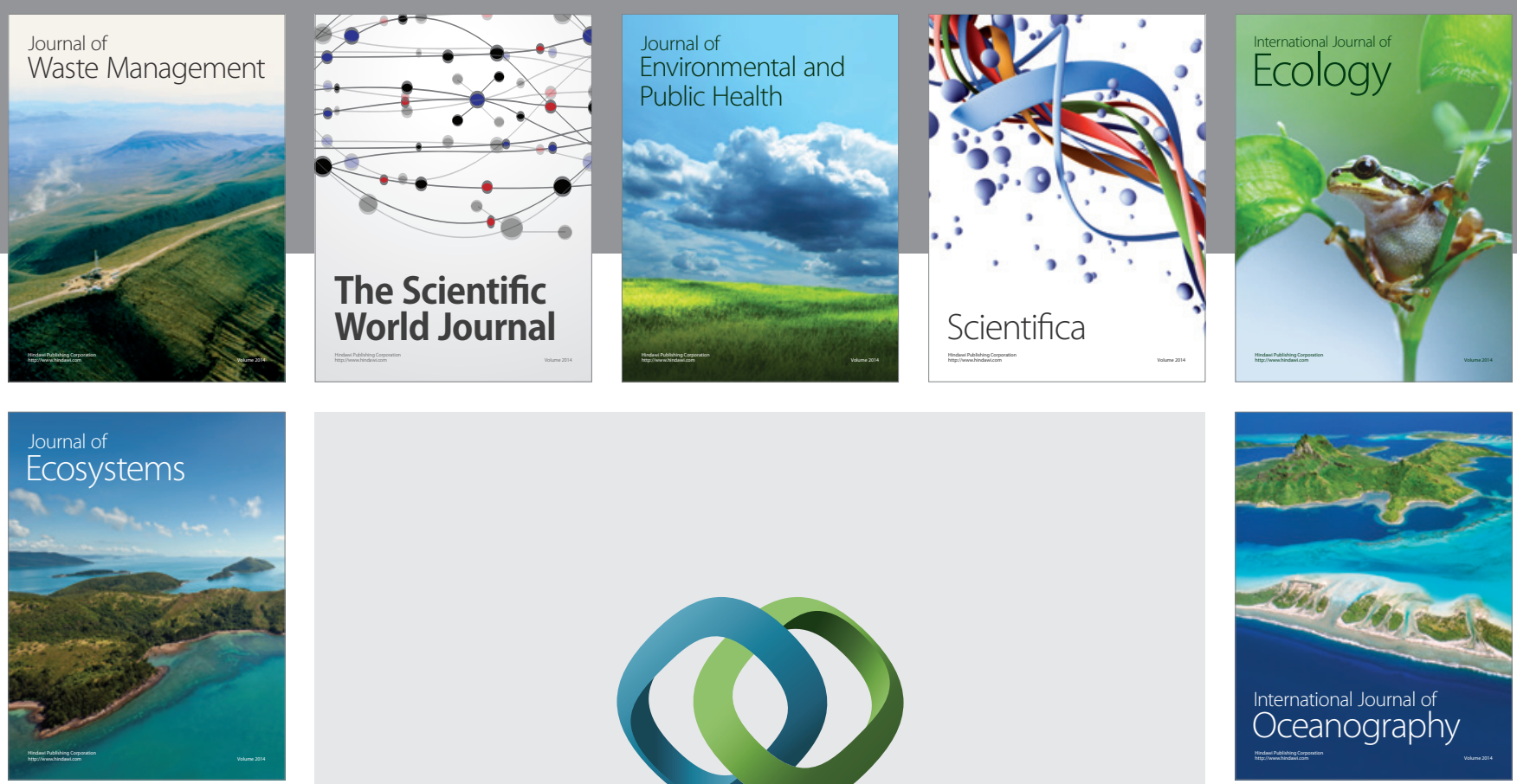

The Scientific World Journal
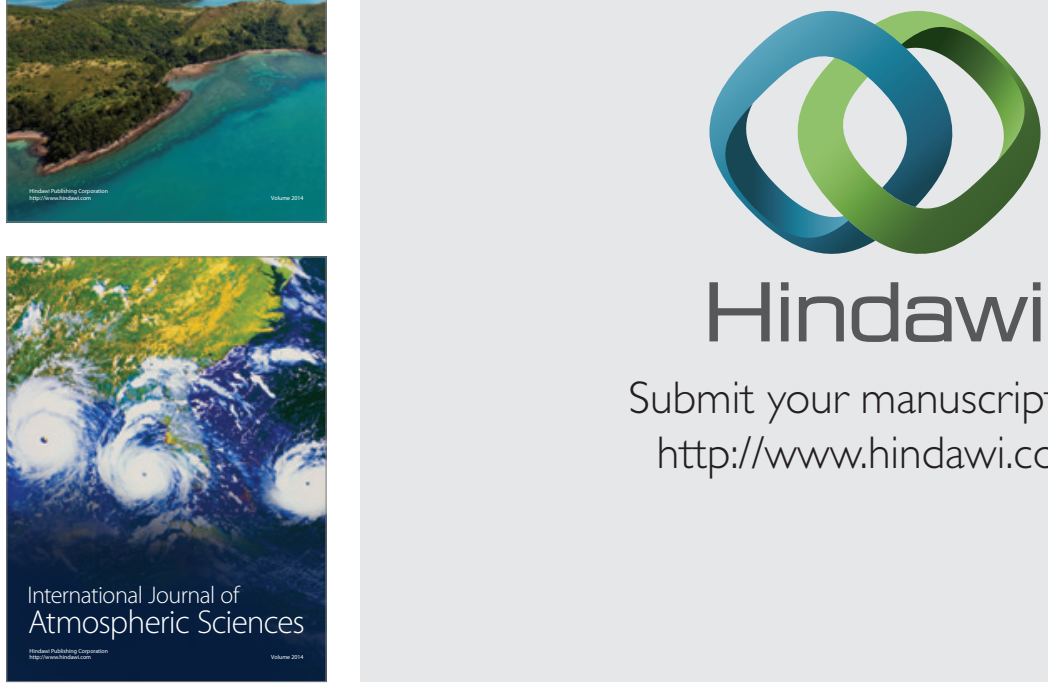

\section{Hindawi}

Submit your manuscripts at

http://www.hindawi.com
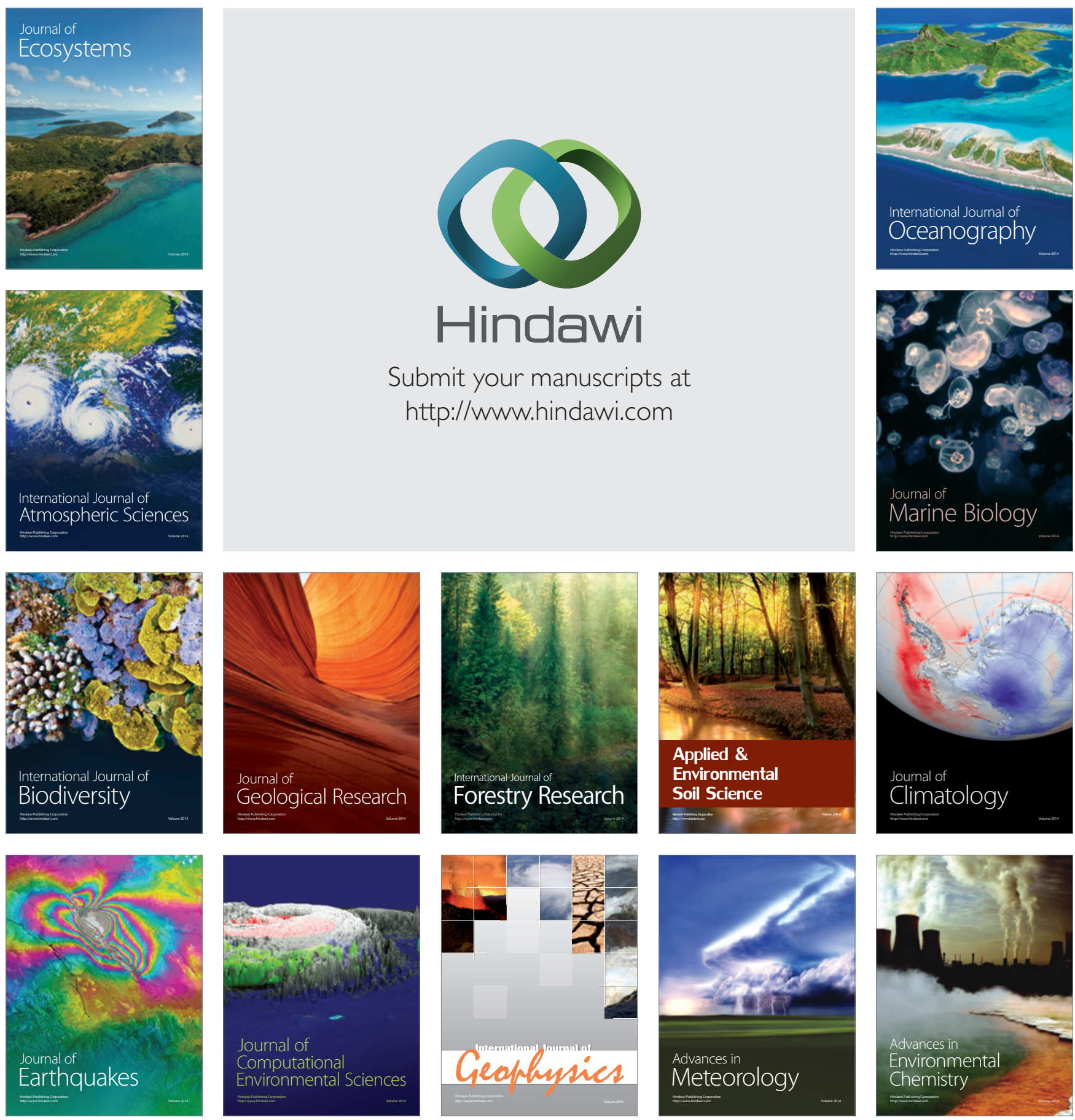